\title{
Short History of Enlargements: From a European Community of Six to the European Union of 28
}

\author{
Giuliano BELLEZA, Rome [Roma]*
}

with 1 figure and 5 tables in the text

\section{Content}

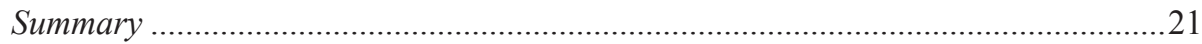

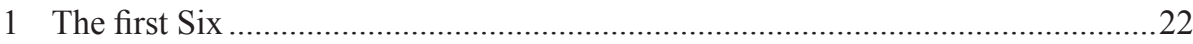

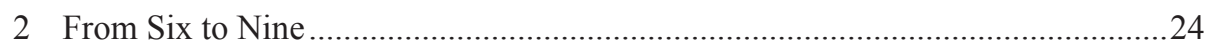

3 From Nine to Fifteen and to the Soviet disruption................................................27

4 EU of Fifteen, Kosovo and Euro …………………............................................

5 New millennium begins with the Euro and the largest enlargement ever..............32

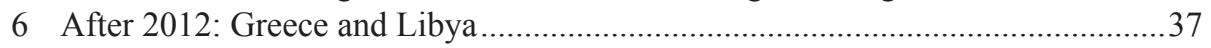

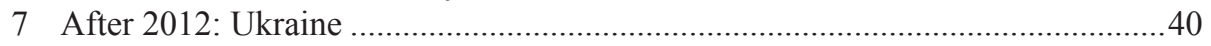

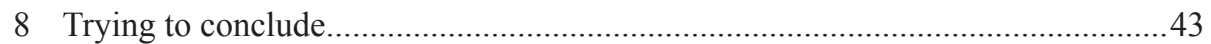

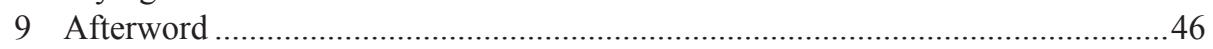

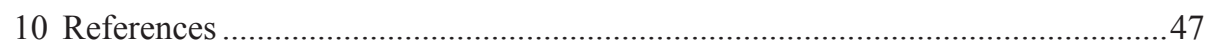

\section{Summary}

This article, part of my autobiography that looks at my life from childhood to my rather old age, seen in relation to European history and dominated by the laborious construction of a supranational association of states. When the first attempt by a small group of states saw the formation of the European Coal and Steel Community (ECSC), I was very glad and even more so seeing a few years later the birth of the three European Communities. The following period saw a flowering of industrial activity. The same Italy, a mainly agricultural state, soon became an important industrial one: even more so as part of the European Communities (EC).

* Giuliano Bellezza, PhD. Prof., Home of Geography, Villa Celimontana, Via della Navicella 12, I-00184 Roma, Italy; email: giuliano.bellezza@uniroma1.it 
Somehow disappointed by the French reluctance to welcome the United Kingdom, I was eventually glad when in 1973 there was the first accession. Unfortunately, shortly afterwards it became clear that the primary interest of the United Kingdom was not European, but trans-Atlantic in nature. In any event, some years later the accession of Greece, Spain, and Portugal, seen by a young Italian man working in a university, in the Faculty of Humanities, this was pure cultural honey. However, real life also showed a division between modern, more developed states in the northern European Union (EU), and the poorer Mediterranean area.

After the economic boom, in the 1980s, things were no longer so good: not bad, yet, but perhaps stagnating, and in many states the public expenditure were more than revenue, meaning more public debt.

A turning point came in 1989 with the disruption of the Soviet Union and a large number of Eastern European states asking to join. At the time I had already become somehow selective: I feared that in a community, more is not necessarily better. At the same time two big decisions were discussed: the adoption of a common currency, and not all the 15 members accepted it; the free movement of people inside the EC, and even in this case there were opposition. Free movement of capital and not of people? No, this was not my idea for a democratic community. The population of the subsequent twelve new member states, on the opposite, were glad to move westwards in search of employment.

The failure of the Leman Brothers Bank provoked a global crisis, and when some recovery was beginning, three more, very bad events occurred: the economic failure of Greece, the birth of ISIS - the only aggressive Muslim movement in the Southern Mediterranean coast - and the crisis in Ukraine. For some days there has been war, not in EU, but on its borders. Spring 2015 begins in the worst ever period of the EC, and our common future seems to me ever more doubtful.

\section{The first Six}

I have had an opinion on the European Communities (EC) since the institution of the first European Coal and Steel Community (ECSC): I was 14, and my feeling was based on my previous war experience. My experience, very little indeed, occurred from 5-8 years old, in Rome [Roma]: at that time I was proud, because, thanks to my child's ration card I received milk, bread, pasta, wheat flour and oil for a special price, more than other members of the family. However, surely, no special treatment could be expected during bombings: a very fearful kind of noise.

I felt that the war was really finished when I was nearly nine, and could spend some days in the countryside; the first night, newly arrived, I ate two eggs in a single meal: I could easily have had one more, just asking, but I was satisfied, indeed. The difference between peace and war appeared to me with shining evidence became 
clear to me in a matter of seconds. Consequently, years later, I was very happy for the institution of the various ECs: I perceived it to be insurance against war and was optimistic about its future development.

In Italy it is commonly said that at the base of the Treaty of Paris (signed in 1953) was the Italian Manifesto di Ventotene, written by some Italian intellectual opponents to Fascism and, as such, restricted for years in the small island of Ventotene. Their intention was to develop an alliance at the end of World War II to avoid any more war in Europe, and this was what France proposed to Germany with the Monnet-Schumann Declaration. Not the German composer, this Robert Schumann was the French Minister of Foreign Affairs. Italy, Belgium, the Netherlands and Luxembourg could enter in the European Coal and Steel Community (ECSC) as founders. The economic success went beyond any forecast, especially for a country such as Italy, lacking coal as well as iron. The 'Six' decided to enlarge the cooperation to the sectors of industry, agriculture and the peaceful use of atomic energy, which happened in 1958, with the Treaty of Rome (my town, one more reason of enthusiasm).

First critic: the Schuman Declaration used a very simple language, proposing clear objectives and how to obtain them. The treaties of Rome proposed greater objectives and goals, but the language is very diplomatic: the governments had no difficulties applying the disposition in a way well adapted to their national interests. Nothing has been said about common military force, as the United Kingdom was in strong opposition, so as not to disturb the common operation under the umbrella of NATO (clearly directed by USA).

A common market is a friendly economic organisation, and consequently German war debts were significantly reduced, to be slowly given back; moreover, in the time of free movement relative to steel industry, Italy could maintain for some years custom fees on such products. Only thanks to this more than peaceful attitude did the steel production start in Italy an incredible cycle of growth: from four to more than 22 million tons in the period 1954-1964, and custom fees could be abolished in a few years. German, French or Italian big automobile producers could have easily invaded the Netherlands, but a gentleman's agreement allowed Dutch car enterprise DAF to continue its activity.

It should also be stressed that the very peaceful Treaties of Rome had been signed during the coolest period of the Cold War: for the Six, the following years are still remembered as "the Economic Boom".

Yet, some kind of globalisation was beginning: 1957-58 was also the International Year of Science, when scientists of the USA and the Soviet Union decided to exchange information, trying to make it possible to carry out joint research; scientists of nearly all the world applauded enthusiastically. The end of the International Year didn't stop the cooperation, and amongst the first global outcomes was the plate tectonics theory. All this seems incredible, because in the same time East-West Cold War also was based just on science-based weapons of mass destruction. (The space race was not 
totally inspired by a peaceful approach.) I was ending my university studies, studying geological science, and I became ever more convinced: the best tools to make peace could be provided by science.

One more event has to be remembered. In 1960, Austria, Denmark, Norway, Portugal, Sweden, Switzerland and the United Kingdom founded the European Free Trade Area (EFTA), a kind of international organisation allowing economic activities to operate in the area with no restrictions: the most powerful could enlarge, swallowing the smaller. Many liberal (maybe too many) economists were convinced that the free market was more efficient than a common market, while inside the communities, EFTA was interpreted as an attempt to boycott ES, triggered by the United Kingdom.

Soon after and in the following years, the economic success of ECs remained incomparably superior.

\section{From Six to Nine}

The following events, until the joining of the United Kingdom, have been influenced by relevant changes. The first has been the election of De Gaulle as president of France. In his vision, the European Communities should become an entity not simply competing in economy and culture with the USA and the Soviet Union, but with the aim to win. France should use the EU rules to this end, with minimum delegation of national sovereignty. New members would be welcome, but accepting of the tendency to world primacy, excluding war, of course.

At the same time, Germany could no longer be ironically dubbed the "economic giant and political dwarf". Ten years after the Treaty of Rome nothing relative to Germany could be defined as dwarf. France, with De Gaulle and his foreign affairs minister, Couve de Mourville, and Germany, with Chancellor Adenauer and Minister Hallstein, were on opposite fronts on many issues, but agreed on the construction of a strong EC, able to compete with the two superpowers. Ten years after the Treaties of Rome, the EC figures of growth in Gross Domestic Product, private consumption, salaries and commerce - internally as well as internationally - were by far better than that of the USA, and the Soviet Union couldn't even to be taken in consideration. To remember the short opinion of the former English Prime Minister Winston Churchill: "the USSR has not the possibility to produce at the same time enough butter and guns". The space race spoke clearly: the Soviet Union launched the first men in orbit in 1961, but only seven years later, the USA sent the first men to the moon, and brought them back safely.

The EC wasn't investing much in this field, but preferred to develop the steel industry: the former German 'Konzerne' in the Ruhr region, whose production had been strongly reduced for some years, were now surpassed by the new coastal 
integrated complexes in France, Belgium, Netherlands and Italy, so that EC soon became the world's largest producer. In the same coastal areas, a number of very large oil refineries were constructed, and in this field also the EC soon reached pole position in the world.

By the mid-1960s, the problem of a United Kingdom accession couldn't be avoided, the main problem being that the French President De Gaulle had a strong Euro-continental vision, while the United Kingdom's one was very atlantic, and in discussions its delegates were limited by their international relations with USA. France demonstrated its reluctance to follow USA pre-eminence in NATO, withdrawing from this military alliance, then proposing a common leadership ('directorium') in the EC to Germany, but in this case Germany didn't accept. Of course, Germany had a strong moral debt to the USA, having been designated as main shield against a possible Soviet invasion of Europe. This had given an advantage to Germany, forcing it in the same time to demonstrate gratitude to USA.

All the rules of EC had been established after years of discussions, and the United Kingdom (UK) wanted to discuss everything again, before joining: most of all, the UK representative seemed to consider joining to be a concession to EC. Even worst, sometimes they didn't appear well-prepared on the discussion themes. Of course, there were very different economic interests. To quote but one, in international commerce the EC countries had to apply similar rules to the rest of the world, and France - only after long difficult discussions - obtained particular relations for the former African colonies. The UK asked for exceptions not only for former colonies, but even more comprehensively for all of the Commonwealth: finding a solution was very difficult. In any event, it appeared evident that all the countries, including the six founders, were more than reluctant to cede a minimum of sovereignty to the EC, especially in the international contacts with the rest of the world. Some weeks before the signature, the UK wanted to establish a permanent information exchange with USA, under French pressure the EC refused to accept and the UK opposed a veto to a joint conference of EC with the oil-exporting Arab countries. Difficult to understand, in the time of Yom Kippur War, with the following incredible oil price growth. Following February 1974, only French opposition blocked EC accession to a USA-led coalition of oil importers to oppose the Arab oil producers. Years before, De Gaulle feared the UK was a USA Trojan horse in the EC, and surely the UK was demonstrating to be still following Churchill's recommendations on the three circles of special relations: Commonwealth, the USA, Europe, but not European Communities. I slowly began thinking that le Général had probably been right: once a fan of an EC enlargement, I began thinking it better to adopt a more selective attitude.

Together with the UK, Ireland, Denmark and Norway also applied: all of them members of EFTA, with the exception of Ireland strictly tied to the UK, anyway. To solve the problem, in the agreement signed $22^{\text {nd }}$ January 1972, the status of Associated States was created from 1973, leaving them four more years to solve the custom problems 
with the remaining EFTA members. During 1972, all the new potential members organised a national referendum on the issue. To universal surprise, the Norwegian population rejected joining. Some said because of the fear of being invaded by poor southern immigrants or by foreign fishing boats in the rich Norwegian waters, other gave responsibility to the recent discovery in these waters of rich offshore oil fields. Someone, however, proposed a fourth explanation: young Norwegians couldn't deny the economic success of EC, but were criticising the lack of advanced social public structures: they wished the institution of EC to take social equity more seriously, and not only economic success; moreover, they criticised all the EC states, for paying too much attention to national, instead of common interests. In that time I tried to persuade myself that this was what the young Norwegians really wanted; thinking today, I am afraid, this only means I was still too romantic. The decisive Norwegian reasons had been, most likely, the first quoted.

In fact, after the first halcyon years, the level of action by the EC decision-making institutions, where all the member states appoint a representative, had lowered: the members were no longer only dedicated and expert persons. They were chosen now by each country's most powerful party, and with the new countries, their members were to be augmented. The most important institutions are the Council of Ministers (or simply Council) and the Executive Commission. The Ministers (of agriculture, industry or other, depending on the discussed issues of the day) are nominated by different countries to represent national interests. Obtaining advantages depends on their personal negotiating ability: nobody could blame them, this being their duty. To avoid confusion, the very similarly named European Council is made up of the head of state or government, with no legislative power, only providing the Union with general political directions and priorities.

The most important EC institution is surely the Executive Commission. Its members should only work in the common interest of EC; they elect a Commission Chair, and during their five-year term, as well as the chair, they must forget their nationality. In many national parliaments, the stronger party alone decides who nominate in the commission, but as a whole the commissions have not been criticised, beating all suspects. After 1979, when the first European Parliament was elected, these national representatives were subject to the parliament approval: this is a serious examination, and sometimes the nomination has been denied.

The Six were ironically called "the Little Europe", and with the enlargement the surface grew from 1.164 to 1.523 million $\mathrm{km}^{2}$. Still small, compared to the 9.636 million $\mathrm{km}^{2}$ of the USA or 22.275 million $\mathrm{km}^{2}$ of the Soviet Union, but "Little Europe" wasn't used any more. Probably the reason is due to the population growth, from 191.107 to 254.9 million, this also to be compared with USA, 208.8, and Soviet Union, 247.5.

However, a handicap remained the lack of common foreign policy. The EC didn't have reserves of oil or gas (except for the promising discoveries in the North Sea), and all countries were looking for supplies. The Soviet Union could easily persuade single 
EC members to negotiate, separate from the others, obtaining special prices to buy oil, gas and more, while the EC as a whole could have bargained better. However, the Nine had even less common foreign policy than the Six, something, which was destined to increase following further accessions: this still remains the main limitations to building a real entity worth of being called a community (and today Union).

Table 1: Europe of Nine, statistical figures, 1973

\begin{tabular}{|l|r|r|r|}
\hline \multicolumn{1}{|c|}{$\boldsymbol{S T A T E}$} & $\mathbf{1 , 0 0 0} \mathbf{k m}^{\mathbf{2}}$ & $\mathbf{1 , 0 0 0}$ resid. & \multicolumn{1}{c|}{ density } \\
\hline Belgium & 30.5 & 9,711 & 318 \\
\hline Denmark & 46.1 & 4,992 & 116 \\
\hline France & 547.0 & 51,700 & 95 \\
\hline Germany & 248.5 & 61,674 & 248 \\
\hline Ireland & 70.3 & 3,014 & 43 \\
\hline Italy & 301.2 & 54,345 & 180 \\
\hline Luxembourg & 2.6 & 347 & 133 \\
\hline Netherlands & 36.6 & 13,330 & 364 \\
\hline United Kingdom & 244.0 & 55,788 & 229 \\
\hline EU Comm. & $\mathbf{1 , 5 2 3 . 8}$ & $\mathbf{2 5 4 , 9 0 1}$ & $\mathbf{1 6 7}$ \\
\hline & & & 11 \\
\hline Soviet Union & $22,275.1$ & 247,459 & 22 \\
\hline USA & $9,363.1$ & 208,842 & \\
\hline
\end{tabular}

The sources of the tables and the figure have been taken from the official annual and quarterly publications of EUROSTAT, like Eurostat Pocketbook - Key Figures on Europe; Eurostat compact guides-Basic Figures on EU; Eurostat Regional Yearbook.

\section{From Nine to Fifteen and to the Soviet disruption}

The Nine suddenly had to face the oil crisis following the Arab-Israel war of 1973. Israel won by far, with the usual decisive help of USA, conquering some more parts of Palestinian territory. The growing oil prices had a strong impact on all the EC industrial activity, based on oil import and manipulation, and covering the majority of energy needs. Today we can blame the absence of environmental care, but, as a matter of fact, nobody cared about this kind of problem in that time. Private car circulation 
was very often prohibited on Sunday, but just to spare gasoline: no one cared too much for the existence of particulate, as few scientists knew about. The United Kingdom had been lucky enough to find offshore oil, and the Netherlands also found some productive fields of this kind. For all the others it became crucial not to antagonise the Arab states or the Soviet Union, always without a common foreign policy.

A good step toward a more unified Union was the first election of a European Parliament in 1979, which has ever since been elected every five years. It has legislative power, but only for special procedures; usually it only adopts the law proposals of the Commission; on the other hand, it nominates the president of the Commission, and examines the Commission's proposal before ratifying; in case of dissention. Still, the Commission remains the main proposer of laws, giving the voters for Parliament a sense of disillusion: not surprisingly the turnout always remained low. The European citizens seem to believe the Parliament a rather useless institution.

Notwithstanding some dissatisfaction among the EC members, other states wished to join, but didn't match the requirements of democracy. As soon as dictatorships were overcome, Greece in 1981, Spain and Portugal in 1986 could join, so lifting to twelve the number of EC members.

Table 2: Europe of Twelve, statistical figures, 1986

\begin{tabular}{|l|r|r|r|}
\hline \multicolumn{1}{|c|}{$\boldsymbol{S T A T E}$} & $\mathbf{1 , 0 0 0 \mathbf { k m } ^ { \mathbf { 2 } }}$ & $\mathbf{1 , 0 0 0}$ inhab. & \multicolumn{1}{c|}{ density } \\
\hline Belgium & 30.5 & 9,858 & 323 \\
\hline Denmark & 43.1 & 5,111 & 118 \\
\hline France & 547.0 & 54,335 & 100 \\
\hline Germany & 248.5 & 61,021 & 248 \\
\hline Greece & 132.0 & 9,741 & 74 \\
\hline Ireland & 70.3 & 3,537 & 51 \\
\hline Italy & 301.2 & 57,291 & 190 \\
\hline Luxembourg & 2.6 & 365 & 141 \\
\hline Netherlands & 36.6 & 14,529 & 428 \\
\hline Portugal & 92.4 & 10,129 & 110 \\
\hline Spain & 504.7 & 38,342 & 76 \\
\hline United Kingdom & 244.0 & 55,058 & 229 \\
\hline Eur. Comm. & $\mathbf{2 , 2 5 6 . 0}$ & $\mathbf{3 1 9 , 3 1 7}$ & $\mathbf{1 3 7}$ \\
\hline & & & 25 \\
\hline USA & $9,363.1$ & 233,980 & 13 \\
\hline Soviet Union & $22,275.1$ & 278,784 & \\
\hline
\end{tabular}

Sources: see Table 1 
With the new members, the Mediterranean area, cradle of European culture, was in the EC: something that I was very glad of. The North-South economic gap enlarged beyond any doubt, but considering also the situation of Ireland, this could better be called as a centre-periphery gap. A European Fund for Regional Development was established, to help the more disadvantaged regions. In the theme of population movements, the South to North immigration had stopped in the early 1970s, as all industry were suffering from the recent oil crisis. To facilitate population movements inside the EC, in 1985 an agreement was established in Schengen: at the moment it was only a proposal for the gradual abolition of border checks. Five years later, the Schengen Convention proposed the institution of a Schengen Area, operating like a single state: a total abolition of internal border checks, while enforcing control for travellers and merchandise entering or exiting the area. Even states outside of the EC could possibly participate, it was written.

At the same time, the EC began to be seen as an attractive area for immigrants not only from developing countries to the traditional industrial destinations, such as the United Kingdom, France, Netherlands or Germany. Now, two new different immigrant movements, though still small, began to arrive: one, under the influence of the Catholic missions in India, Latin America and in former African colonies, was composed of female housekeepers directed mainly to Italy or Spain, the other, more diffused and composed of people looking for employment coming from Eastern Europe.

This was interpreted as the final demonstration that the EC was now an international organisation, attractive, but also friendly. For dozens of years, nobody had shown aggressive intention to any part of it. I am not tired repeating that the EC, becoming a wider and more populated entity should have more adequate foreign policy, while only France, no longer member of NATO, insisted for a Unified European Defence Force. In any event, no agreement could ever be reached. The majority of states seemed to be satisfied participating in NATO, without questioning the USA superiority. Most of all, the strength of the Soviet Union appeared to be weakening, looking embarrassed and unable to stop the anti-Russian riots in Poland, under clear influence of the Vatican and Western powers.

An efficient minister of foreign affairs of the EC could probably put together the various different signals arriving from Eastern Europe: beginning with workers emigration, strong anti-Russian riots starting from the old major labourer strongholds, like Gdańsk, growing Soviet weakness in international activity as well as in space research. Someone should have forecasted a possible great turmoil in the Soviet Union. Nobody did, but this was exactly what happened, so the EC arrived totally unprepared to the upside-down of 1989: for the second time, shortly after the oil crisis of 1973. 


\section{EU of Fifteen, Kosovo and Euro}

During the early 1990s, many decisions were made by the EC, and not in the classical towns, like Brussels [Bruxelles/Brussel] or Strasbourg. In 1992, in Maastricht (Netherlands), the treaty merging the former Communities (Coal and Steel, Common Market, Euratom) in a single European Union (EU) and deciding the adoption of a common currency, the Euro $(€)$ was signed. The following year the Schengen Treaty could become operative, though this happened only some years later.

Still in 1993, in Copenhagen [København], the criteria defining state eligibility for new members were defined. This was not relative to Austria, Finland and Sweden joining as they surely matched all the possible democracy requirements: their accession was completed in 1995, so beginning the EU of Fifteen. The real problem concerned the important number of states wanting to join from the former Soviet sphere of influence and Yugoslavia, because this could open to NATO membership: an openly military alliance. The USA was enthusiastic, but Russian opposition was even stronger. Once again the lack of a common foreign policy was felt by Europe, but the majority of politicians in the EU official agencies were unmoved.

In 1990, a very important event changed the geographical map of Central Europe, when West and East Germany reunified. In that moment, Germany became the most populous state within the EU, with more than 80 million people, while the UK, Italy and France were still below 60 . Since that moment Germany became more internationally active.

From 1995, the member states began to join the Schengen Area of free movements, and in 2000 all had joined with two exceptions: easy to understand, they were (and still are) the UK and Ireland. The decision to leave free the movements of capital and not of people was, to my eyes, very bad, above all in the UK, where some islands are known as tax havens.

In 1998, the European Monetary Institute was substituted by a more powerful European Central Bank, with a strong dissatisfaction for nearly all national central banks. The usual opposition by states to any kind of sovereignty mandate to Europe was even clearer when ratifying the Amsterdam Treaty in 1999. Here the Maastricht decisions were definitively adopted, giving increased powers to the European Parliament, with an emphasis on citizenship and the rights of individuals, new rules on employment, aiming for a community area of freedom, security and justice. At last the necessity to reform the institutions for the next foreseen enlargements was stressed and the necessity of a common foreign and security policy was also mentioned, but with very little success. Many states tried to oppose to a more powerful parliament, and I'm still trying to find an answer to a simple question: why did they adhere to a supranational Union?

In any event, this had been the more active decade of the EU, but procedures remained intolerably slow. The text of the Amsterdam Treaty was completed in 
Amsterdam in June 1997, but negotiations began in Messina in June 1995. The text was then signed in October and endorsed by the parliament in November. Eventually, but only after two more referenda and thirteen ratifications by national parliaments, the procedure was at last approved. With Norway the only exception, all the democratic countries of Western Europe were joined in a supranational unity, whose main scope was to avoid any war in the continent. This was, I thought, the realisation of the Manifesto di Ventotene and of the Schuman-Monnet declaration.

Soon, the newly born EU was involved in the worst European scenario after World War II: real wars among the different states in the Balkan region. Serbia was always involved. NATO was in favour of a strong intervention to protect Kosovars, and following the idea of US President Clinton, France and the UK gave all possible

Table 3: Europe of Fifteen, statistical figures, 1995

\begin{tabular}{|c|c|c|c|}
\hline STATES & $1,000 \mathrm{~km}^{2}$ & 1000 resid. & density per $\mathrm{km}^{2}$ \\
\hline Austria & 83.9 & 8,029 & 96 \\
\hline Belgium & 30.5 & 10,130 & 332 \\
\hline Denmark & 43.1 & 5,215 & 123 \\
\hline France & 547.0 & 56,615 & 104 \\
\hline Finland & 338.1 & 5,078 & 15 \\
\hline Germany & 357.0 & 81,539 & 228 \\
\hline Greece & 132.0 & 10,264 & 78 \\
\hline Ireland & 70.3 & 3,526 & 51 \\
\hline Italy & 301.2 & 57,282 & 190 \\
\hline Luxembourg & 2.6 & 385 & 149 \\
\hline Netherlands & 36.6 & 15,341 & 452 \\
\hline Portugal & 92.4 & 9,853 & 107 \\
\hline Spain & 504.7 & 38,748 & 76 \\
\hline Sweden & 411.0 & 8,816 & 21 \\
\hline United Kingdom & 244.0 & 58,395 & 239 \\
\hline European Union & 2689.7 & 369,216 & 137 \\
\hline Russian Fed. & $17,073.0$ & 148,249 & 9 \\
\hline USA & $9,363.1$ & 289,162 & 28 \\
\hline
\end{tabular}

Sources: see Table 1 
support. Given the geographical position, Italy couldn't refuse NATO forces the use of Italian air space and of the NATO bases in Italian territory. Some EU states spoke against any kind of air bombing. Russia, openly in favour of Serbia and wishing for only diplomatic intervention, sustained this position even in the UN Security Council. The East European states wishing to join in the EU succeeded in not taking a clear position, with the exception of Slovakia, in favour, and Bulgaria, opposing. (Possible explanation in the relations with Russia: Slovakia wanted the most political distance possible, Bulgaria wanted reduce this distance as much as possible.) In the rest of the world only Japan, Malaysia and Australia were in favour of bombing, while China, India, Indonesia, Vietnam, Pakistan and others (nearly half of the world's population) strongly condemned the bombing. Disagreement in the UN Security Council made it impossible to take a position.

However, on-the-ground fighting and air bombing took place in 1998-99, with thousands of casualties, largely civilians; in the following years, mass graves were discovered, and the dedicated UN International Criminal Tribunal for former Yugoslavia, in The Hague ['s-Gravenhage] condemned representatives of both Serbia and of Kosovo for war crimes, and even criticised in some cases of NATO bombings. War had appeared once more in Europe, after 50 years and some EU members actively participated: surely not in the EU area, but just at walking distance.

\section{New millennium begins with the Euro and the largest enlargement ever}

At the beginning of third millennium my romanticism was nearly at an end, and I was doubtful about the opportunities presented by the next round of EU enlargement, the biggest ever. Still, when on the $1^{\text {st }}$ January 2002, the Euro ( $€$ ) became the official currency of EU. I took this as a good step in the right direction. However, a strong problem remained, as the European Central Bank does not have a mint: all the currency is only minted by the national banks, though they are not free to mint as much as they want.

To my dismay, the same year, two EU States didn't adopt the Euro: the rejection by the United Kingdom was nearly expected, while the Denmark refusal resulted somehow surprising. In any event they are expected to join and asked to try to meet the criteria to do so. A couple of years after, the expected main news was the accession to the EU of ten new members: Cyprus, Czechia, Estonia, Hungary, Latvia, Lithuania, Malta, Poland, Slovakia, and Slovenia. Some more were in waiting, and joined in the following years: with Bulgaria, Croatia and Romania the total number reached 28, and in 2014, Serbia also began talks. The newcomers were expected to adopt the use of Euro, but six of them have not yet done so. Kosovo and Montenegro decided to do so. 
As of 2014, the EU surface is 4.381 million $\mathrm{km}^{2}$ and the population more than 507 million. Now as a core part of EU law, all new EU member states are legally obliged to join Schengen, as soon as technical requirements have been met; it now covers an area of 4.312 million $\mathrm{km}^{2}$, with a population of more than 400 million people.

Table 4: Continental Europe of Twenty three, statistical figures, 2008

\begin{tabular}{|c|c|c|c|}
\hline STATES & Area $1,000 \mathrm{~km}^{2}$ & Population million & Density \\
\hline Austria & 84.0 & 8.1 & 96 \\
\hline Belgium & 30.5 & 10.4 & 504 \\
\hline Czechia & 79.0 & 10.2 & 129 \\
\hline Denmark & 43.1 & 5.4 & 125 \\
\hline Estonia & 45.2 & 1.4 & 30 \\
\hline Finland & 338.1 & 5.2 & 15 \\
\hline France & 547.0 & 59.8 & 110 \\
\hline Germany & 357.0 & 82.5 & 231 \\
\hline Greece & 132.0 & 11.0 & 83 \\
\hline Hungary & 93.0 & 10.1 & 109 \\
\hline Ireland & 70.3 & 4.0 & 56 \\
\hline Italy & 301.3 & 57.9 & 192 \\
\hline Latvia & 64.6 & 2.3 & 36 \\
\hline Lithuania & 65.3 & 3.4 & 53 \\
\hline Luxembourg & 2.6 & 0.5 & 175 \\
\hline Netherlands & 43.0 & 16.2 & 391 \\
\hline Poland & 312.7 & 38.2 & 122 \\
\hline Portugal & 92.4 & 10.4 & 113 \\
\hline Slovakia & 49.0 & 5.4 & 110 \\
\hline Slovenia & 20.3 & 2.0 & 99 \\
\hline Spain & 506.0 & 41.9 & 83 \\
\hline Sweden & 411.0 & 9.0 & 20 \\
\hline UK & 244.0 & 61.4 & 252 \\
\hline European Union & $3,777.8$ & 459.7 & 121 \\
\hline Russ. Fed. & $17,073.0$ & 144.5 & 8 \\
\hline USA & $9,363.1$ & 290.8 & 31 \\
\hline
\end{tabular}

Sources: see Table 1 
Some EU functionaries tried to write a European Constitution, but in 2004 in Rome [Roma] many states didn't accept it. In 2007, a new text was proposed and discussed in Lisbon [Lisboa], and once again, it was not adopted. For the last time, I promise, I ask my usual question: why did they adhere to a supranational union and hold elections to have representatives in the parliament? Was it only to boycott the Union?

The first years of the $21^{\text {st }}$ century could be a check about the willingness of the new members on the issue. Everybody knew that their economic figures were, in 2003, well below that of Western Europe, even when compared to the Mediterranean states, known as the least developed within the EU.

In the following year there were improvements everywhere: rather good in the northern, more advanced states, somehow less in the Mediterranean, and better in the new member states. However, they were starting from a lower level: their per cent increases were high, but not that much in absolute data. This situation had been more or less forecasted, but in 2007 everything was suddenly turned upside-down by events in the USA: the failure of the Lehman Brothers (LBB Bank) resulted in a severe economic downturn, and this time global is the only adequate adjective. Many critical economists said that this sudden turmoil wasn't at all unexpected: the only doubt being why the major rating companies were still rating that bank as AAA.

The four graphs below show the evolution of significant figures from 2003 (the year before accession), 2008, when the LBB effect was felt, and 2012, when recovery was slowly proceeding. The acronym EAST here is the mean data relative to the new members from continental Eastern Europe (therefore, not including Malta and Cyprus). $A D N$ means Austria, Denmark and Netherlands, as representatives of the wealthy part of EU, while GIP stands for Greece, Italy and Portugal, representative of the poorer part. Italy is included in this category not so much for per-capita GDP, this being the same as registered in the United Kingdom, but for the state economic debt, among the worst of the world (old debts, mainly accumulated in the 1980s and early 1990s). Inside the three categories there were differences from one country to another, but always small.

Per-capita GDP shows a similar trend across the three categories: good increases following enlargement and strong crisis following LBB. The interesting fact is that during the period the ADN figure passed from 33.6 to 39.7 thousand Euro, that is $+18.1 \%$. For the GIP group the change has been from 20.4 to 22 , growing only $13.7 \%$; in Eastern Europe, GDP per capita passed from 7.1 to 11.5 , an increment of $62 \%$. Considering the inflation of the period, in Western Europe purchasing power remained on the same level, while in the new member states there has undoubtedly been an improvement. 
Figure 1: Development of economic and welfare indicators 2003-2012 by country groups

GDP per capita

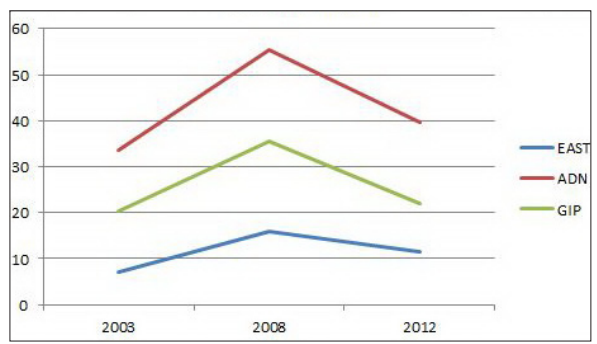

Social care

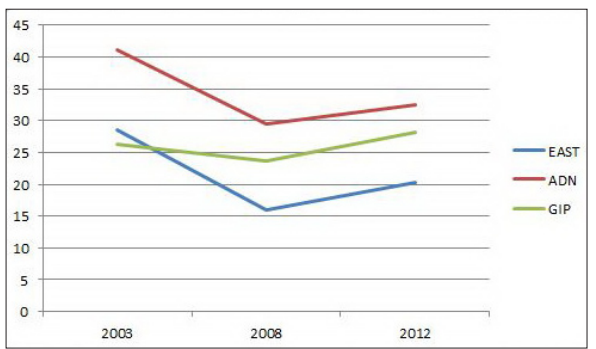

Unemployment

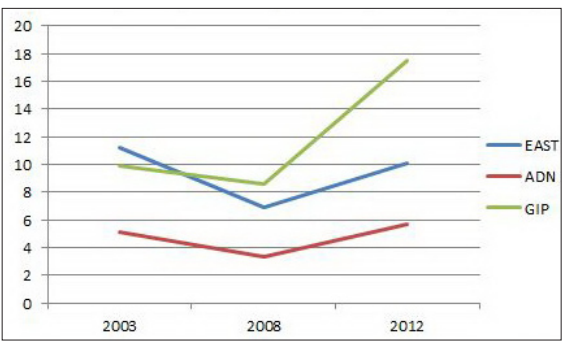

Human Development Index

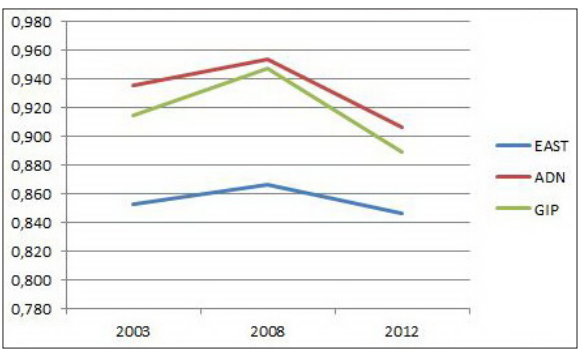

Sources: see Table 1

Different were the trends in unemployment, apart the general trend of all the graphs: in the first year the unemployment was decreasing, and after LBB it started growing. In this case, ADN saw the unemployment grow $11.7 \%$ in eight years, while in GIP the growth was an incredible 76.8\%. Particularly surprising is the developmentin Eastern Europe: after the initial decrease an increase has been registered after LBB, but, all in all, in 2012 the unemployment was $0.8 \%$ less than it was when they joined. Both graphs show that for Eastern European countries, membership has proven to be a good choice.

The evolution of the state expenses for social care, a kind of investment lowering throughout Europe up until 2008 is different: in the aftermath all states tried to invert the trend, and in this case the best results were obtained in the Mediterranean. This was the only area where, four years after LBB, the expenditure for social care was $7.2 \%$ more than in 2003. In the more wealthy countries there has been a decrease of $21.1 \%$ and, this also a surprise, the maximum decrease has been registered in Eastern Europe, with $22.3 \%$. 
Table 5: European Union of Twenty eight, statistical figures, 2012

\begin{tabular}{|c|c|c|c|}
\hline Name & $\begin{array}{c}\text { Area } \\
1,000 \mathrm{~km}^{2}\end{array}$ & $\begin{array}{l}\text { Population } \\
\text { in millions }\end{array}$ & Accession \\
\hline Austria & 83.9 & 8.451 & 1 Jan 1995 \\
\hline Belgium & 30.5 & 11.161 & Founder \\
\hline Bulgaria & 111.0 & 7.284 & 1 Jan 2007 \\
\hline Croatia & 56.6 & 4.262 & 1 Jul 2013 \\
\hline Cyprus & 5.9 & 0.9 & 1 May 2004 \\
\hline Czechia & 78.9 & 10.516 & 1 May 2004 \\
\hline Denmark & 43.1 & 5.603 & 1 Jan 1973 \\
\hline Estonia & 45.2 & 1.325 & 1 May 2004 \\
\hline Finland & 338.4 & 5.427 & 1 Jan 1995 \\
\hline France & 547.0 & 65.633 & Founder \\
\hline Germany & 357.0 & 80.524 & Founder \\
\hline Greece & 132.0 & 11.063 & 1 Jan 1981 \\
\hline Hungary & 93.0 & 9.909 & 1 May 2004 \\
\hline Ireland & 70.3 & 4.591 & 1 Jan 1973 \\
\hline Italy & 301.3 & 59.685 & Founder \\
\hline Latvia & 64.6 & 2.023 & 1 May 2004 \\
\hline Lithuania & 65.2 & 2.972 & 1 May 2004 \\
\hline Luxembourg & 2.5 & 0.537 & Founder \\
\hline Malta & 0.3 & 0.4 & 1 May 2004 \\
\hline Netherlands & 41.5 & 16.78 & Founder \\
\hline Poland & 312.7 & 38.533 & 1 May 2004 \\
\hline Portugal & 92.4 & 10.487 & 1 Jan 1986 \\
\hline Romania & 238.4 & 20.058 & 1 Jan 2007 \\
\hline Slovakia & 49.0 & 5.411 & 1 May 2004 \\
\hline Slovenia & 20.3 & 2.059 & 1 May 2004 \\
\hline Spain & 504.0 & 46.704 & 1 Jan 1986 \\
\hline Sweden & 450.0 & 9.556 & 1 Jan 1995 \\
\hline United Kingdom & 243.6 & 63.73 & 1 Jan 1973 \\
\hline
\end{tabular}

Sources: see Table 1 
The last graph refers to the Human Development Index, considered the most indicative, including wealth, education and life expectancy. 0.900 is considered the good level and in 2008 all the Western European states were well above 0.940, while in the Eastern part the mean was around 0.880 (with the wonderful exception of Slovenia, at 0.920). Even this data followed the general trend, with an initial improvement everywhere, followed by the post-LBB decrease. The AND countries all remained above 0.900 , while the Mediterranean countries fell below 0.890 and the mean value in Eastern Europe lowered only from 0.853 to 0.846 in nine years.

In January 2014, Serbia began accession negotiations, but there were still problems with the complete definition of borders with many Balkan entities. However, during that period many very difficult events occurred in the immediate surroundings of the EU and within the EU itself. The lack of a common foreign policy appears ever more serious, and the rapid increase from 15 to 25 and finally 28 members made things yet more difficult. I had always been doubtful about the enlargements: the peaceful and powerful Union, with members ready to help each other, which I had hoped for a long time ago, seemed to be vanishing. My old enthusiastic and optimistic spirit was shifting to a more pessimistic vision; in the concluding paragraph I'll try to explain the reasons why my mood, far from improving, was - and continues - to worsen.

\section{After 2012: Greece and Libya}

Germany, once a political dwarf, has long been seen as dominating the EU actions, but some economists now question its economic gigantism. It is a giant, beyond any doubt, but what is its health? And how much of it relies on control of the financial policy of the EU? Maybe the austerity imposed on the EU, with the help of a few of the wealthiest states, is somehow advantageous to the economic giant and especially its banks?

The austerity imposed everywhere is the base of the populist, Eurosceptic and anti-Euro movements now growing everywhere, with a large number of supporters in the European Parliament. In the $7^{\text {th }}$ Report on Security in Europe of the Unipolis Foundation (presented in the Italian Parliament on $24^{\text {th }}$ February 2015) showed that in all EU states the majority of the population asked does not trust the institutions; the only exception being Germany, but even there, only with a meagre $53 \%$. France and Poland follow, slightly above $40 \%$. In Poland, $71 \%$ oppose the possible adoption of Euro, and this figure grows to $84 \%$ in the United Kingdom. In Italy, $30 \%$ will like to abandon Euro, and, believe it or not, 37\% in Germany. In France the figure is about $23 \%$, but reaches $48 \%$ in what is now the strongest political party, the Front National. Speaking of parties, among members of Britain's United Kingdom Independence 
Party (UKIP), 92\% of supporters will oppose the adoption of Euro - a really difficult situation given that the common currency has been the major project proposed and approved in the EU, along with the institution of a Central Bank: called Central, but with no real influence on the various national banks.

Let's examine the major crisis now facing EU: as I wrote above, one is inside the EU - Greece - and two on the borders: Ukraine and the so-called ISIL (Islamic State of Iraq and the Levant). I don't blame the Norwegians and Swedish for not considering these as dramatic problems, but geographic position means something: in Italy these really are fearful emergencies. Seen from here, immediately after their solutions, a federal European Union appears possible to be shortly put on the agenda.

Beginning with Greece, the problem here is an economic one, and doesn't appear to be solved but only procrastinated following the proposal made by the Greek Prime Minister to gain some more time for an economic recovery. And today the 'solution' only demonstrates where the problem lies. The Greek economic crisis originally started because of counterfeit appraisals of past governments; the debt to the EU being substantial, the subsequent governments asked for a long time to try and repay. With the intervention of European Commission, Central Bank and International Monetary Fund (IMF), the answer was hard-line: debt, fines and interests should be repaid quickly, starting immediately to gather money by means of an internal policy of restriction and austerity. Forced to reduce social expenditure and with the impossibility of any kind of productive investments, the economic crisis grew immediately. By the way, almost being driven to default had been the result of the austerity imposed over some years by IMF and World Bank to countries in economic difficulty in all continents. Greece tried to find help in the EU, to no avail. There was no hope from the United Kingdom, always refusing to give one more pound to help EU budget, while some other states, e.g. Finland, Norway and the Netherlands, joined Germany in the steadfast refusal. The new party, Syriza, and its founder and leader Tsipras, won by large margin and started a new round of negotiations with the European Commission, IMF and the European Central Bank. It took some months for Greece to obtain the actual four months delay (not a solution), while among the reluctant new members, Slovakia found the time to clearly state its unavailability to any kind of help. What is to be stressed is that when European Commission, Central Bank and IMF began to take a milder attitude, the opposition until a few days ago came from German Chancellor, Angela Merkel, and when she also appeared flexible, the strongest opponent became the Director of the German National Bank and the Minister of Finance. Once, when I was young and romantic, I would have asked how was it possible that the Director of a national bank and a minister could slow down a decision of international agencies and also of their Prime Minister, but today I am rather sceptical, maybe cynical, surely pessimistic about the future of EC, without a rapid, radical change in the efficiency of its institutions. 
Seen from Italy, the second nearest crisis is on the Southern Mediterranean coast, where the so-called Arab Spring flowered in 2011. It appeared then that the main danger was the presence of the Libyan president, Muammar Gaddafi, and following a joint initiative of the United Kingdom and France, favoured by NATO and USA, some EU States (amongst them Italy) gave armed support to the national rebels. For some international scholars (e.g. KAGAN 2002) it is not completely true to say that the EU comes from Venus and US comes from Mars. The peacefulness of the EU appears somehow hypocritical: its weaponry is still relevant only against a land invasion from the East, and even in this case, it counts on the protection of the US and NATO. This happened some years ago, during the wars among states emerging from former Yugoslavia (see above). After looking at the southern Mediterranean coast, we'll examine the Ukrainian case, finding an even stronger confirmation of this.

In Libya, Gaddafi was made prisoner and savagely killed, and ever since the country (?) has been governed (?) by chaos. After the Arab Spring, no southern Mediterranean state was able to establish what would be considered 'democracy' in the Western World: maybe it is time to question ourselves about many 'Western values', which we deem as universal (including democracy) and try to impose on peoples whose values are different, not to mention the methods we employ. This takes us to the most urgent emergency in Libya, where a good part of the territory is now 'governed' by the ISIL. Italy has for many years been an unwilling first refuge of poor immigrants, embarking from the Libyan coast on derelict boats: about 160,000 landed in 2014, while some hundreds (maybe thousands) died, drowned in the sea (periodical publications of Amnesty International and Caritas Italiana). Europe considered this to be an Italian problem, and some months ago forced Italy to stop the program "Mare aperto" (Open Sea), accused of rescuing the shipwrecked, also in international waters. Once Mare aperto was stopped, the EU started the "Triton" program in international waters, with a small number of European boats engaged in trying to stop and send back the boats overfilled with desperate people to Libya. This operation was an outrage, just on the basis of the so-called Western values; moreover, Triton's efficiency was close to zero. After some time, Italian values prevailed over the Western, and national coast guards and fisher boats started again to rescue the people on sinking boats as soon as they received an SOS, even those in international waters.

Things changed when ISIL moved out of its original areas in Iraq and Syria and in Libya, monopolised the gesture of desperate people. There are hundreds of thousands of people on the Libyan coast, mainly arriving from Sub-Saharan and Eastern Africa and now forced to depart, regardless of sea conditions. After a few miles the pilots activate the automatic pilot, leave to somebody a new mobile phone, take a speed boat and go back. In this way they earn money to operate in social media, sending every day alarms to Italy, pretending to have missiles already pointed at Sicily, possibly reaching as far as to Rome, and above all alerting about a terrorist invasion. Of course, no terrorist is likely to arrive on one of the old boats, which are very likely to wreck. 
The real problem is that the appeals are aimed at convincing supporters in Europe to carry out terrorist attacks, even alone, to try and kill as many infidels as possible. It is worth noting here that an infidel is any human being not strictly following the opinions (fatwa) of the self-nominated Caliph Al Baghdadi, and that the majority of their victims are Shia Muslims. The diffusion of outrageous killing of western hostages or Christian Copts, Chaldea and others is part of their propaganda destined to the Western world.

Many doubts exist about a real, solid connection between the Middle Eastern ISIL and the Libyan organisations, but stopping their internet activities aimed at stimulating terrorism in Europe is necessary. It is common knowledge that there are already hundreds of young Muslims born in Europe, educated to values different from ours: for them carrying out a suicide bombing in a supermarket or attacking any store suspected of anti-Islamic activity is a very good move. Moreover, dying in action is the most valuable gesture to finish life and going directly to Paradise. This has already happened in Central and Northern Europe, yet still, not enough attention has been paid to the ISIL presence in Libya. The French President Hollande, after two terrible terrorist attacks in Paris, was ready to send armed forces into Libya, sure that he would find support from the United Kingdom, the USA, NATO, and possibly Italy, as four years before. However, the failure of the 2011 intervention was still too fresh, so only Italy declared itself ready, but only after obtaining UN aegis: nothing has been decided yet. In the meantime the boats overfilled with desperate people are trying daily to land on the Italian coast. The only cold comfort is that this is not the route of terrorists, while it is sad to note the usual powerlessness demonstration of the EU: passing to Ukraine we will talk about an even worse case.

\section{After 2012: Ukraine}

The actual causes of the Ukraine crisis are to be sought in the perennial conflict between the USA and Russia. After some unpleasant Russian actions (Egypt, Syria, Wikileaks/Snowden), Obama began fostering the anti-Russia movements in Kiev [Kyiv]: the population of the Ukrainian capital, aiming to join the EU and NATO, began strong riots. President Yanukovych opposed with violence, until forced to resign (abandoning the country and finding refuge in Russia). With the EU remaining - as usual - without a firm position, the mere possibility of Ukraine joining NATO was enough for Putin to demonstrate decisive action: political, not based on weapons. He fostered a referendum in the Crimea [Krim] to secede from Ukraine and enter in the Russian Federation: the population being Russian-speaking, the result was a resounding approval.

The US has a tendency to intervene without enough knowledge of a local situation, but it seems incredible that the EU didn't know at the time of all the good 
reforms done in recent years by Putin. His interventions received warm welcome from the middle and lower classes: more efficient public administration, more equality in taxation and more rapid justice, but most of all, minimum salaries had been raised. Nothing like this had been done yet in Ukraine, Belarus and other former members of the Soviet Union. In the particular case of Ukraine, President Yanukovych, with close ties to Russia, had been on trial for bribery, as had previously happened to Yushenko and Timoshenko, who had already been convicted (PellicCIARI 2014).

Back in history, the original causes date from to 1950s, when Nikita Khrushchev gave to Ukraine, then a member of the Soviet Union, the oblast (region) of Crimea. In 1991, Ukraine gave Crimea the status of an autonomous republic (the same it had as part of the Soviet Union). Eventually, in November 2013 the western Ukrainian population, anti-Russian and wanting to negotiate membership of the EU, began rioting against President Yanukovych in Majdan Square (central Kiev, so the movement took the name of Euromajdan). On the other hand, the Russian-speaking population in the eastern region of Ukraine supported the president's position. The immediate response by the president in Majdan was very hard, causing several casualties. As usual, the EU didn't intervene, and the occasion was seized on by the ministers of foreign affairs for Germany, France and Poland (this one representing all the new members): they went to Kiev, asking Yanukovych to adopt a milder approach, with no result. Soon after, the Ukrainian army rebelled against the president, who was forced to seek refuge in Russia. Petro Poroshenko, elected president in the resulting election, soon tried to establish more contacts within EU for possible accession. In March 2014, Crimea, with undeniable help from Putin, decided to secede from Ukraine, and was warmly welcomed into the Russian Federation. The two eastern provinces of Ukraine, Donetsk [Donec'k] and Lugansk [Lugans'k], both with a strong majority of Russianspeakers, also asked for independence. The Ukraine government tried once more to begin talks to enter in the EU (and NATO), finding a divided EU: not much enthusiasm was forthcoming in Western Europe with comprehensible reaction from Russia, and a strong, favourable attitude in the Baltic and Eastern States.

Poroshenko tried to frustrate the use of Russian language, and thus decided the population of the Donetsk and Lugansk regions to follow Crimea in requesting independence. The request was now unstoppable, and very hard, as it could trust on Russian forces deployed along the border. On the same level has been the reaction of the new Ukrainian President Poroshenko, who accused Putin of helping the secession and soon sent the army to Donetsk and Lugansk, trying to block movements. An Italian historian (CARACCIOLO 2014b) tried to explain the final crisis, observing that Obama and Putin were losing control, the first over Poroshenko, the second over the Ukraine independence movements: that's why the line between fierce fighting and war was soon crossed.

Of course, in this conflict the USA and Russia have different feelings: important but peripheral for the USA while vital for Russia. The EU is in the middle, and with 
its usual inability in foreign relations. This time the problem is more complicated than ever: while the EU and USA have enjoyed centuries of uninterrupted friendship, it is not the case for Russia. In this case, there is today an insurmountable energetic dependence. This problem has been further complicated by the post-WWII desire to foster American interests.

It is necessary to look at the hydrocarbon traffic between the EU and Russia. The EU imports from Russia 24\% of gas, and more than a half of that passes through Ukraine. Ukraine also imports from Russia, and pays for it, but not always; when this happens, Russia closes the supply, and no gas arrives in EU. Until 2011, when the North Stream (a gas duct under the Baltic Sea, also from Russia) began operations, the percentage of gas passing through Ukraine was 80\% (FLoros 2014a), and now the northern EU seems to no longer be having problems. This will probably have a positive influence on Merkel-Putin relations, explaining Merkel's strong activities to facilitate the Russia-Ukraine dialog.

Southern EU dependency on the Ukraine passage remains vital. Years ago attempts were made to realise a large gas pipeline called Nabucco (for some years dubbed 'flag project'), relying on production from Azerbaijan, Kazakhstan, Iran and Iraq: too much for the USA, which in hiding managed to impede the project: one of the usual mistakes of the USA. As a matter of fact, Russia is developing a new line, starting from Shah Deniz in Azerbaijan, the Blue Stream (under the Black Sea) and a trans-Turkey passage, will join a Trans-Adriatic pipeline (TAP) to the Balkans and Italy: this way all of Europe (not only the EU) will be embraced in a dangerous hug of Russian pipelines (FLOROS 2014b; INDEO 2014) bypassing Ukraine. Beyond any doubt, Russia relies on European purchases, but is very careful to limit this dependence: a 30year agreement established in 2014 with China will easily substitute the income from Europe. Starting from 2018, the contract speaks of 1 trillion $\mathrm{m}^{3}$, for a total payment in the range of 400 trillion US dollars (payment in Yuan after some years). Maybe Nabucco wasn't a good solution, but now, with the exception of the northern states, the EU dependency on Russia is increased (FLOROS 2014a).

In the last globalised years, US production has increased beyond any forecast, due to the non-traditional method of production: shale gas and fracking. Can the EU take advantage of this production? Not really and for several reasons: non-traditional oil is more expensive, the US is still using all of its production and, moreover, has not enough plants to liquefy the gas while, on the other side of the Atlantic, the EU has not enough plants for re-gasification. It has to be noticed that good possibilities for nontraditional oil appear to exist also in Poland, Czechia and Slovakia but, different from US, EU is still very cautious about this kind of production.

Back to Ukraine, it is rather easy to understand that the weapons the EU has to hand, such as threat of economic sanctions against Russia, cause little worry. The USA is no longer available to support practical interventions and is very cautious about sending arms to the Ukrainian army, while EU members are divided on the problem. 
The new members have a basic anti-Russian attitude, together with the fear of a strong Russian reaction, and understood that NATO protection is always less probable. The more established members are divided, with only Denmark, Netherlands, Norway, Sweden (nearly) ready to intervene (CARACCIOLO 2016); the others show no enthusiasm to participate, and only under the uncertain NATO umbrella. (Russia and the probable China vetoes will exclude the UN.)

For the past few months, the Italian Margherita Mogherini has been responsible for the EU's foreign affairs and has shown herself to be more willing to operate than the high representatives that preceded her. But she was not supported by the EU institutions. Everybody thought that in order to avoid war it was necessary to organise talks between the presidents of Ukraine and of Russia, with some arbitrators. After Obama, of course, being the most powerful man in the world, the second should obviously be the High Representative of the European Union for Foreign Affairs and Security Policy: a denomination as flamboyant as it is empty. In fact, representing the whole EU was the French President, Hollande, together with the German Prime Minister, Merkel; actually she could have gone alone. GidDENs (2014) stresses that in the EU the real decisions are not taken by the EU1, the official institution, but by a hidden EU2, mainly Merkel. Hollande accompanies her, while Sarkozy could have once had some influence. Today all EU decisions are taken, overtly or behind the scenes, by Germany: in this case overtly. The discussion reached a decision, to became effective not immediately, but with some days delay: after a couple of weeks some fights were still happening, and the rebel regions of Donetsk and Lugansk conquered some more $\mathrm{km}^{2}$, including Debaltsevo, the main regional railroad hub. Now the Crimea is de facto part of the Russian Federation, and probably this will be the destiny of the self-nominated republics of Donetsk and Lugansk. This region is important; in 1920 Trotsky accused the European powers of fighting the Soviet Union not for democracy, but to access the coal of Donetsk and the iron ores of Krivoy Rog (Lugansk).

\section{Trying to conclude}

When in 2012 the EU was awarded with the Nobel Prize, a lot of people strongly criticised the decision. However, the motivations written by the committee are wellbalanced and undeniable, stating that EU had "for over six decades contributed to the advancement of peace and reconciliation, democracy and human rights in Europe". In a synthetic SWOT analysis to highlight issues and assist in attempting a conclusion, these words expressing rather well the main strength of the EU, gave it a global good reputation.

The main weakness is the reluctance of all members to cede any part of sovereignty to the EC institutions, giving it the reputation of a non-united union. 
The major threat is the difficulty to build multiracial and intercultural societies in countries where the population was used to emigration, and recently became desirable to very poor immigrants. Our poor people see the newcomers as disloyal competitors, accepting work for very little money.

Our major opportunity is the presence of a large population (only China and India are more populated), with a high degree of education and a sufficient computer literacy in young people, but: more in their use of social networks, than in their knowledge of computers.

However, the very good strength and opportunity are de facto weary, while the mentioned weakness and threat are hurdles that will be difficult to overcome. This weakness leads to the inability of the EU to adopt a real foreign policy, and this is a major handicap in all its relations with the rest of the world: enjoying a good moral reputation offers no economic advantages. In industrial as well as in agricultural economy, EU products encounter obstacles even in internal commerce and the situation is even worse when dealing with the rest of the world. Extending to the diffusion of cultural products, as movies and TV broadcasting, France obtained the adoption of a cultural exception: movies from the rest of the world shouldn't be more than half of European television broadcasting. There has been no possibility for the European national television to do so, due to the concurrence of the private TV, which never considered following the law. Private television always and easily found in their country some political party taking their part, receiving in exchange favourable transmissions. This clearly demonstrates that the lack doesn't concern only the EU foreign policy: there are no real common policies even within the EU, always due to the refusal of states to cede any sovereignty.

This a vital point: how much are EU member states really determined to realise the original goals of the Monnet-Schuman declaration? It related not only to the production of coal and steel use without custom fees, but for some years Adenauer, the German Chancellor, left the coal mining region of Saarland to France, and some years later France gave it back to Germany. Both were available to cede not only sovereignty, but a material part of the state, though temporarily. Since the United Kingdom joined, the impulse towards a real union faced more opposition. In any event, the EU was maybe the first economic entity of the world, with no political influence of the two superpowers, US and Soviet Union.

Not at all interested in a strong EU, in the 1980s the presidents of the superpowers changed the world asset: Reagan decided to definitely win the Cold War, helping the members of the Warsaw Pact, in the name of human rights. Gorbachev decided that it was convenient for the Soviet Union to give them more independence. In a matter of months, these states decided to take complete independence, and the Iron Curtain fell, with the physical destruction of the Berlin Wall. Actually, only one superpower remained, and the unified Germany became the most important member of EU. The new independent states wanted to join the EU, and the German Chancellor, Kohl, saw 
this as sure economic gain for his country and talks progressed quickly. I have already said that not all the community of 15 members really shares the original common goals, and this is even more so in the community of 28 .

Let me pass now to the issue of threat, relative to the difficulty of building a solid multiracial and intercultural society. The problem is to give strength to a galaxy of movements asking for exits from EU and the Euro, as mentioned earlier in this article. In the United Kingdom, the Netherlands, France and mainly Italy (TuRAto 2014) they are divided from extreme neo-liberal right and extreme left, but discussing common action in the European Parliament, on the common anti-EU and anti-Euro base. It is a clear sign of diffuse europhobia, and the explanation is not on the side of the demand, but on the side of the offer (CARACCIOLO 2014a). The EU doesn't invest enough into general progress, and so into the welfare state, that is in what is called smart growth: higher education, innovation, $\mathrm{R} \& \mathrm{D}$, info-communication technology and so on (GIDDENS 2014) and this is true for the states, as well for private industries.

I signalled as a major opportunity the presence of a large population with sufficient computer literacy in young people, mainly in the use of social networks. This is not enough, because there is a generalised dissatisfaction among young people, shown by their retreat from active politics. Participation in elections is decreasing, while the socalled brain drain continues to increase: our best and well-prepared young people are emigrating, looking for job at their level in the most advanced countries. They are not so much interested in the difficult building of an intercultural society in the EU: their rebellion is not political, but individual.

Without building an attractive European democracy, we foster the populist, antiEU movements, and I think that the best remedy is coming back to the ideas of the EU founders: I don't mean the states, but the people who expressed the idea. To give an example, the USA is financially organised with a central bank, governing a unique currency: the only way to build a solid federative organisation. EU governance has a central bank, with national banks in all member countries (without the possibility to modify the international exchange rate) and different currencies. It took years to the central bank to reduce the debt of the impoverished states, with the strong opposition of the wealthy ones: fearing for the so-called stagflation, they make it nearly impossible for the poor countries to make productive investments.

This way, the threat will win over the opportunity, and the hope is that a road could open to a better-organised international association, whatever the cost, even with less members. The best moment to cut with the past and take a new road was probably soon after 1989, but Germany was still facing the problem of re-unification and reorganisation of its federal structure, and could even think about leading the federation of Europe.

To conclude, more than 70 years have passed by since a small boy, at the end of World War II, lived in Rome under German occupation. Today he still wishes for a powerful and peaceful EU association, confederation or federation; he thinks that this 
can happen only if Germany, today an economic and political giant, decides to take a lead in this direction. For this, a German chancellor is needed that cares more for common development, and less about 'fiscal compact' and economic austerity.

In any event, the old man that the small boy became would like to conclude as much as possible with a positive observation. In today's EU, the most conservative movements want to stop the immigration of people not sharing our 'Western values': they simply (want to) ignore that these values are not accepted by the majority of EU inhabitants. For these (let me say: for us) the main value is the individual freedom to make decisions about their own life, the only limit being the freedom of the nearest neighbour (and of all other human beings).

\section{Afterword}

The opinions I expressed are based on a huge flood of essays, press articles, radio and TV broadcasting: in the bulk I like to quote some of the ones, which exerted the maximum influence. Fundamental for the very latest events is the Italian geo-political monthly magazine Limes and, to review the overall vision, the book of Anthony GidDEns "Turbulent and Mighty Continent" (2014).

Even before the introduction of Euro, bitter debates started among the monetary scholars, and are now at a climax. A positive view is expressed by Guy Sorman: "Why Europe Will Rise Again", in The Wall Street Journal, 17 $7^{\text {th }}$ August 2012. Despite being a right-wing thinker, as the majority of today opponents, he is rather positive about the action of the European Central Bank's director in defending the Euro, and is guardedly upbeat when it comes to the future of it. Totally negative and stated in definitive terms is Martin FeldsteIn's opinion in "The Failure of the Euro", in Foreign Affairs, 13 $3^{\text {th }}$ December 2011. A similar rather unbalanced idea is Timothy GARTON AsH's one in "The Crisis of Europe: How the Union Came Together and Why It's Falling Apart", in Foreign Affairs, 20 ${ }^{\text {th }}$ August 2012.

More information can be taken by an article of Shawn TulL: "Two legends in economics wrestle over the euro's future", in CNN Money - Fortune, $9^{\text {th }}$ August 2012, where the positions of Robert MundeLl, Nobel Prize winner and main theorist of Euro, and of Allen MeLTZER, one of the main opponents, are confronted.

Since some months a growing number of experts have said that the global economic crisis has already reached its deepest point, and signs of improvement are now detectable. A very interesting general vision is offered by Klaus ScHwAB, in "The Re-emergence of Europe", Koeln, World Economic Forum, 2012. Nothing to be amazed by his level of information and documentation: ScHWAB is the founder and executive chairman of the Swiss non-profit organisation "World Economic Forum". Well-known through its annual winter meeting in Davos, nowadays attracting more 
than 2,500 participants (private business men and leaders of business companies at world top level), the 2015 Forum Report is available online, but deals mainly with other problems.

A very interesting contribution was the article "What Happened to Europe", published on $2^{\text {nd }}$ August 2012 in The New Republic, a magazine of politics and art commentaries, now in its $100^{\text {th }}$ year. The author of the article is Amartya SEN, Professor in Harvard and Nobel Prize winner.

\section{References}

Amnesty International (ed.), Statistical Yearbook, London, periodical.

Bellezza G. (1974), La Comunità Economica Europea, profilo geografico, Bari, Adriatica Editrice.

Bellezza G. (1978), Geografia. Roma, Editori Riuniti.

Bellezza G. (2009), Lampedusa, primo gradino dell'odierna Odissea mediterranea. In: Ambiente, Società, Territorio, 3-4, pp. 7-12.

Caracciolo L. (2014a), L’Europa che vogliamo. In: La Repubblica (daily), 22 April 2014.

CARAcciolo L. (2014b), Una voce Europea nelle crisi del mondo. In: La Repubblica (daily), 5 August 2014.

Caracciolo L. (2014c), La storia divide l'Europa in due. In: Limes (monthly), November 2014.

Caracciolo L. (2015), Ucraina. In: Limes (monthly), February 2015.

CARAcciolo L. (2016), Ukraina. In: Limes (monthly), February 2016.

Caritas Italiana (ed.), Dossier Statistico Immigrazione. Roma, IDOS, periodical.

Feldstein M. (2011), The Failure of the Euro. In: Foreign Affairs, 13 December 2011.

Floros D. (2014a), Meglio Russia che USA. In: Limes (monthly), April 2014.

Floros D. (2014b), TAP e South Stream. In: Limes (monthly), June 2014.

Garton Ash T. (2012), The Crisis of Europe: How the Union Came Together and Why It's Falling Apart. In: Foreign Affairs, 20 August 2012.

Giddens A., (2014), Turbolent and mighty Continent. Cambridge (UK), Polity Press.

INDEO F. (2014), Nabucco addio, per il gas l'Europa sceglie Tap. In: Limes (monthly), July 2014.

Kagan R. (2002), Power and Weakness. In: Policy Review, 113, pp. 1-18

Kobrinskaia A., Frumen B. (2014), Nessuno conosce noi Russi meglio dei Polacchi. In: Limes (monthly), February 2014, pp.139-150.

Kосн W. (2013), Fracking puts US first in shale gas production. In: USA TODAY, 23 October 2013.

Limes (Italian Magazine of Geopolitics), issue dedicated to Polonia, l'Europa senza l'Euro" (Poland, Europe without Euro). Rome, February 2014.

Ministero DEGLI InTERNi (ed.) (2007), Rapporti sugli immigrati in Italia, periodical. 
MorawSKI I. (2012) <http://temi.repubblica.it/limes/come-la-polonia-e-diventata-ricca/57070> Pellicciari I. (2014), Pompieri o Piromani? In: Limes (monthly), March 2014.

Schwab K. (2012), The Re-emergence of Europe. Koeln, World Economic Forum, 2012.

SEN A. (2012), What Happened to Europe? In: The New Republic, 2 August 2012.

Sorman G. (2012), Why Europe Will Rise Again. In: The Wall Street Journal, 17 August 2012.

Spinelli A., Rossi E. (1940), Il Manifesto di Ventotene. Milano, Mondadori, reprint 2006.

Tull S. (2012), Two legends in economics wrestle over the euro's future. In: CNN Money Fortune, 9 August 2012.

Turato F. (2014), Italia laboratorio del populismo di destra. In: Limes (monthly), June 2014.

United Nations Development Programme (UNDP) (ed.) (2011), UNDP Report. Development and transition.net. 24 September 2011.

United Nations High Commissioner for Refugees (UNHCR) (ed.) (2006), Piano d'azione per la tutela dei diritti nell'ambito dei flussi migratori. Rome, July 2006.

United Nations High Commissioner for Refugees (UNHCR) (ed.), Statistical Yearbook. New York, periodical 